\title{
PREPARING NURSE MANAGERS FOR INFORMED ACTION
}

\section{C.M. MAKWAKWA}

\section{INTRODUCTION}

Nursing Administration is one of the subjects taught to nurses studying for post-registration courses, namely the Diploma in Nursing Administration and B Cur ( $\mathrm{I}$ et A) at Medunsa.

Like other subjects in nursing, it is composed of theoretical and practical aspects. For subjects in clinical nursing or patient care and in nursing education, students have been able to apply theory to practice by being allocated to the real situation where they have been able to actually $d o$. That is, in the wards and clinics where patient care is actually done and in the nursing colleges where nursing students are actually taught.

Students in Nursing Administration, however, have not been able to $d o$. They have been sent to services but have so far only been able to observe what nurse administrators do, been given extra theory on how things are done, and have looked at the products of actions previously taken by nurse administrators, for example, a disaster plan.

\section{PRACTICAL PRESENTATIONS}

In an effort to bridge the gap and thus make the teaching of future nurse administrators more meaningful, students studying towards a Diploma in Nursing Administration were each guided to select an administration topic that could be presented to the class or part of the class more concretely. This was

Mrs C.M. Makwakwa, RN, RM, CHN, BSC (Nursing), Hons BA (Nursing), MA, EdM. Senior Lecturer, Department of Nursing Science, Medunsa.

\section{OPSOMMING}

Studente in Verpleegadministrasie het nie die kans om vaardighede in die praktiese situasie in te oefen nie - hulle kan gewoonlik net waarneem wat verpleegbestuurders doen.

Om hierdie probleem te oorbrug is daar gebruik gemaak van praktiese aanbiedings deur studente op die kursus vir die Diploma in Verpleegadministrasie. Daar was drie soorte praktiese aanbiedings naamlik rolspele, simulasie oefeninge en toepassing in die kliniese area.

In evaluering na afloop van al die praktiese aanbiedings was meeste $(\mathbf{8 0 , 9} \%)$ van die studente van mening dat dit vir hulle 'n groter begrip van die vakinhoud gegee het.

done after a theoretical presentation in class either by the teacher or by the student as a class assignment, under the supervision of the teacher.

The practical presentations were divided into three. Namely, roleplaying, application in the clinical area, and simulation exercises.

\section{ROLE PLAYING}

Role play's were done on the following topics:

- Disciplining for specific problems:

- drunkenness on duty

- continuous late-coming

- Interview for a job (two were done)

- Exit interview (two were done)

The students who presented the role plays wrote the play and asked for co-actors from their peer group.

\section{SIMULATION EXERCISES}

Simulation exercises included the following:

- compiling on-duty lists

- compiling an in-service training programme

- Allocation of ward duties
- Masterplan for personnel allocation

- Formulating a hospital disaster plan

- Writing a memorandum - motivation for personnel

- motivation for equipment

- Budgeting for a clinic

- Budgeting for an extension of a ward

- Allocation of students for clinical experience

- Completing different forms.

Except for the first, third and tenth items, all exercises were done by a small group of students working as a committee.

The presenter or presenters explained each step to the class, that is, the what and why.

\section{Application in the clinical area}

Application in the clinical area was done on the following:-

- Inspection of a ward. (Five inspections were done, each for a specific area in the ward)

- Inspection of a clinic (three inspections were done in different clinics)

- Control of D.D.P.D.

The student who presented the practical experience worked out the checklist, did the procedure and wrote remarks. Brief explanations of the checklist and procedure were given.

\section{EVALUATION}

At the end of each practica, the class, together with the teacher, evaluated the performance.

After all the presentations were done, a questionnaire was given to the students to evaluate the perceived increased understanding of the subject matter. Twenty-one out of 24 questionnaires were returned. 
Table 1 Perceived increase in understanding of Nursing Administration subject matter after practical presentations.

\begin{tabular}{|lcr|}
\hline IMPROVEMENT & $\begin{array}{r}\text { NUMBER OF } \\
\text { STUDENTS }\end{array}$ & PERCENTAGE \\
\hline No improvement & 0 & $(9,5 \%)$ \\
Doubtful & 2 & $(9,5 \%)$ \\
A slight improvement & 2 & $(33,3 \%)$ \\
A moderate improvement & 7 & $(47,6 \%)$ \\
A lot of improvement & 10 & $(99,9 \%)$ \\
Total & 21 & \\
\hline
\end{tabular}

Table 2 Suggestions for improvement of practica

\begin{tabular}{|lcc|}
\hline SUGGESTION & $\begin{array}{r}\text { NUMBER OF } \\
\text { STUDENTS }\end{array}$ & PERCENTAGE \\
\hline The need for more time for practica & 4 & $(18,2 \%)$ \\
More drills necessary & 8 & $(36,4 \%)$ \\
No criticism by peer group & 5 & $(22,7 \%)$ \\
No criticism by teacher and peer group & 1 & $(4,5 \%)$ \\
More topics to be added & 1 & $(4,5 \%)$ \\
More direction in roleplaying & 3 & $(13,6 \%)$ \\
Total & 22 & $(99,9 \%)$ \\
\hline
\end{tabular}

The responses on the perceived increase in understanding were as given in table 1.

The reasons given for the answers forwarded were as follows:

- of the two students who felt only a slight improvement, one gave no reason and the other referred to class presentations of assignments as not having been meaningful. This same student was strongly against criticism by both the teacher and peer group members

- the two doubtful respondents both stated their reasons as not being sure of how to apply the practica in the written examinations

- five of those who perceived a moderate improvement felt that more drills were necessary, that is, all procedures should be repeated

The responses on suggestions for improvement were as given in table 2.

\section{DISCUSSION OF EVALUATION}

The distribution on responses on the preceived increase in understanding of the subject matter is skewed toward the positive (see graph 1).
This strongly suggests that the practica had a positive effect on most of the students, that is $80,99 \%$ (from moderate to a lot of improvement). This implies that there is a place for such practica in the teaching of the subject Nursing Administration.

The reasons given for the answers on the perceived increase in understanding suggest that some students confused the class theoretical assignments with the practica presentations. The two who felt slight improvement both referred to the theoretical assignments. The two doubtful respondents gave reasons that suggests that they were not concentrating on understanding the subject matter as such but rather on how to write the process of each procedure during examinations.

\section{RECOMMENDATIONS}

The following factors need to be taken into consideration when planning the practica:

- more time is needed to be able to - demonstrate the procedure at least once before students do it

- have more than one presentation for a procedure when necessary

- include as many procedures as possible

- More teaching staff may be needed, This will depend on the number of students and the number of procedures

- students need to be helped to be able to accept criticism especially from members of their peer group. It is surprising that despite the fact that it was done as

\section{Graph 1 A Frequency distribution polygon of the responses on the felt increased understanding of the subject matter}

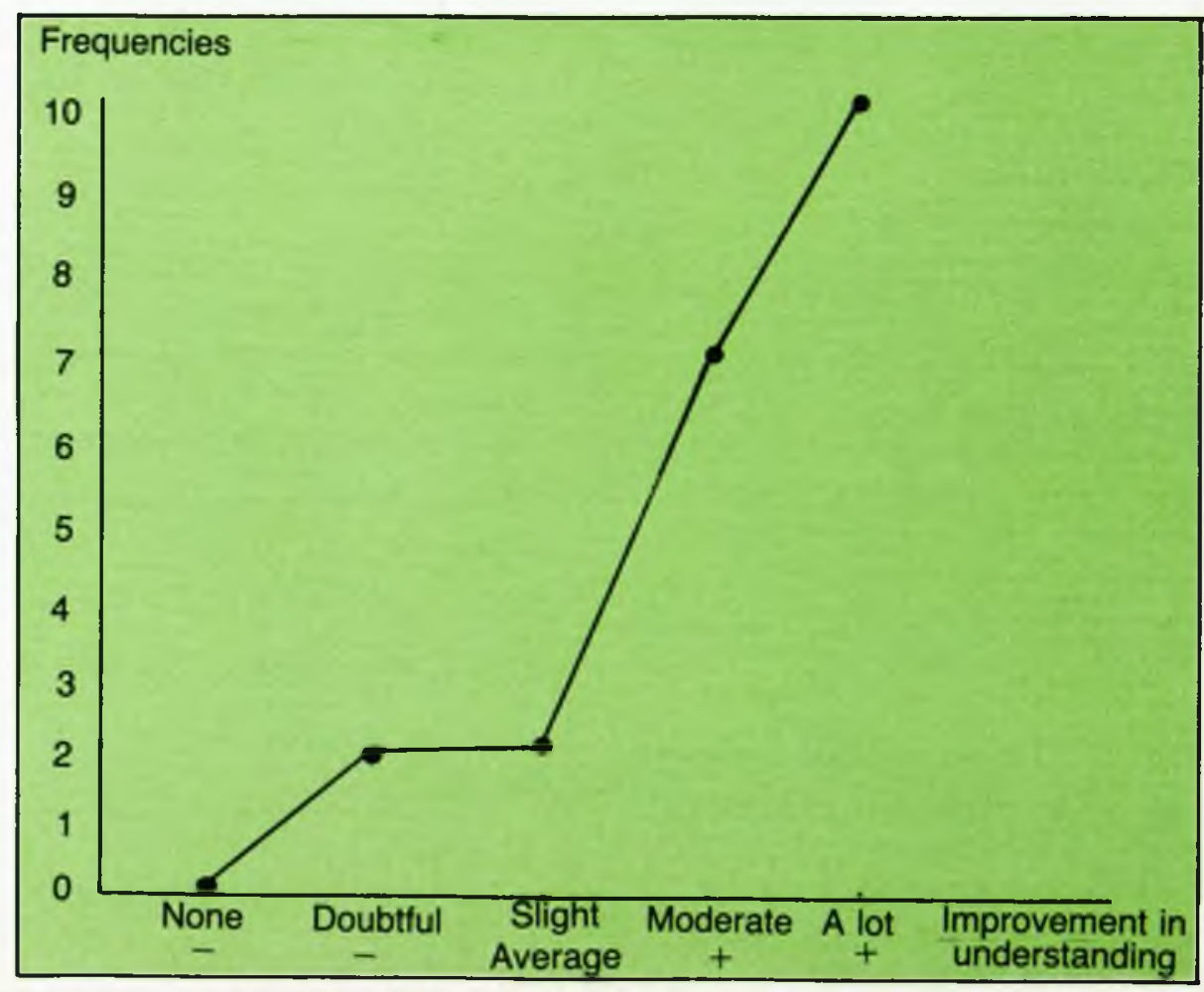


constructively as possible six students $(27,3 \%)$ still did not approve of it. Both the good points and weaknesses were pointed out.

- three students $(13,6 \%)$ felt uncomfortable with different opinions in problem solving. They wanted more direction from the teacher in regard to exactly what the actors in roleplaying should have said and done. This rigidity may be due to the fact that they have internalised the use of policy with no flexibility. It may also be due to the fact that these students were more worried about hard facts for the examination rather than understanding of the subject matter. The fact that the teacher summarised the principles applied in each role play, as given in the earlier lecture, made no impression on them.

(Vervolg vanaf $p$ 14)

\section{DIE GASTRO-INTESTINALE PATROON}

Die diaree en gewigsverlies wat hier voorkom, word gekoppel aan dermkanaalinfeksies as gevolg van Cryptosporidium en ander organismes insluitend alfa herpesvirus 1 en 2 . In 'n hele aantal gevalle bly die oorsaak van die simptome egter onduidelik.

\section{DIE PATROON VAN KOORS VAN ONBEKENDE OORSPRONG}

Hier is daar ook gewigsverlies, malaise en swakheid teenwoordig. In sommige gevalle was daar tekens van Mycobacterium avium intracellulare-besmetting teenwoordig in beenmurg-, limfklier- en lewerbiopsies.

Die meeste van die pasiënte wat van een van die opportunistiese infeksies herstel het, het óf 'n terugval ondervind óf 'n ander infeksie ontwikkel direk na staking van behandeling.

In meer as $30 \%$ van VIGS-gevalle in die VSA en VK, was daar gepaardgaande kaposi-sarkoom teenwoordig. Dit het egter ietwat verskil van die vorm wat aan ons bekend is. Dit kom meer verspreid in die liggaam voor met betrokkenheid van limfkliere, slymvliese en
The above considerations will depend on the particular circumstances.

The sample was small. However, because the students filled in the questionnaire after they had written the final examinations for the year and the fact they remained anonymous, the responses are regarded to be a true reflection of the feelings of the students and can thus be generalised to other students studying the subject.

It is also worthy to note that the students studying towards B Cur (I et $\mathrm{A})$ at the time and who learned of the practica experience by the diploma students requested to have the same experience.

\section{PROBLEMS ENCOUNTERED}

Problems encountered by the teacher were as follows:

ingewande. Kaposi-sarkoom is gewoonlik tot die ekstremiteite beperk. Verder is die maligniteit in VIGS-slagoffers meer aggressief en is die reaksie daarvan op chemoterapie onbestendig (WHO, 1985:31).

\section{SAMEVATTING}

Volgens Wells et al (1985:76) - toe daar gedurende die vroeë dae van VIGS nog net 'n paar gevalle in die VK aangemeld is, en die volle implikasies van hierdie verskriklike toestand nog nie deur eerstehandse kennis ingewin is nie - het dit voorgekom asof die meeste mense hul oë toegeknyp het en gehoop het dat VIGS sou weggaan, of ten minste in die VSA sou bly. Dit het nie gebeur nie!

Die mens wil nou maar net nie leer nie. Hy glo altyd: So iets sal my nie oorkom nie; dit gebeur slegs met andere. Dieselfde was die geval met die Jode gedurende die pes-epidemie van die Middeleeue. So ook die Ierse immigrante gedurende die New Yorkse cholera-epidemie van 1832 (Wells et al, 1985:76).

In die RSA was ons salig onbewus van cholera totdat daar skielik, asof oornag, in 1980/81 gedurende die eerste 24 weke van die cholera epidemie 1964 gevalle aangemeld is. Die hele land was in rep en roer.
- working out of precise checklists for evaluating the presentations took a lot of time and they were not always comprehensive enough

- time allocated for different procedures was not always enough The problem was compounded by the fact that not enough time was available during university hours because students had to attend other lectures.

- not all students could attend all procedures in the clinical setting at the same time because of the large number. Hence some procedures were repeated. Although evaluation of all procedures was done in the classroom for the benefit of all students it is doubtful if it had the same benefit for all students

- not all procedures that should have been repeated were repeated.

Asof dit nie genoeg was nie, het ' $n$ tweede epidemie gedurende 1981/82 uitgebreek met 'n verdere 3407 gevalle gedurende die eerste 24 weke (Dept. of Health, 1985:15).

Daar is geen rede tot pessimisme in soverre dit VIGS aanbetref nie, maar daar moet tog gewaak word teen die moontlikheid (hoe gering daardie moontlikheid op die oomblik ook al mag lyk) dat 'n skielike verhoging in die voorkoms van VIGS ons onverhoeds oorval.

VIGS is vir die eerste keer in 1981 in die VSA aangemeld en 'n plato is nog nie bereik nie. Die VK begin nou eers die impak van VIGS beleef - wat van Suid-Afrika?

\section{BRONNE}

Anon. (1985). AIDS. Milmed. 1(11):5-6, April Department of Health and Welfare kyk South Africa (Republic). Department of Health and Welfare.

Hamilton. Helen K. (Ed.) (1984). Diseases. Springhouse Springhouse Corporation.

Nuttall, Peggy. (1985). AIDS International Nursing Review. 32(3): 78, 79,83, May/June.

South Africa (Republic). Deparment of Health and Welfare (1985). Cholera up-date. Epidemiological comments. 12(1): 14-16, January

Wells, R.; Nuttall, Peggy.: World health organization. (1985). AIDS. International Nursing Review 32(3): 76,77, May/June.

World health organisation. (1985). Acquired immunodeficiency syndrome: the present situation (Report of a WHO Meeting). World Health Forum. 6(1): 30-34. 